Aurora G. Morcillo

(In)visible Acts of Resistance in the Twilight of the Franco Regime

Historical Gender Studies | Volume 2 
Aurora G. Morcillo (PhD) is a professor of history at Florida International University. She is a cultural historian and a gender studies specialist of modern Spain and Post-1945 European history. 
Aurora G. Morcillo

\section{(In)visible Acts of Resistance in the Twilight of the Franco Regime}

A Historical Narration 


\section{Bibliographic information published by the Deutsche Nationalbibliothek}

The Deutsche Nationalbibliothek lists this publication in the Deutsche Nationalbibliografie; detailed bibliographic data are available in the Internet at http:// dnb.d-nb.de

\section{(c) $(1) \Theta \Theta$}

This work is licensed under the Creative Commons Attribution-NonCommercial-NoDerivatives 4.0 (BY-NC-ND) which means that the text may be used for non-commercial purposes, provided credit is given to the author. For details go to

http://creativecommons.org/licenses/by-nc-nd/4.o/

To create an adaptation, translation, or derivative of the original work and for commercial use, further permission is required and can be obtained by contacting rights@transcriptpublishing.com

Creative Commons license terms for re-use do not apply to any content (such as graphs, figures, photos, excerpts, etc.) not original to the Open Access publication and further permission may be required from the rights holder. The obligation to research and clear permission lies solely with the party re-using the material.

\section{() 2022 transcript Verlag, Bielefeld}

Cover layout: Maria Arndt, Bielefeld

Printed by Majuskel Medienproduktion $\mathrm{GmbH}$, Wetzlar

Print-ISBN 978-3-8376-5257-4

PDF-ISBN 978-3-8394-5257-8

https://doi.org/10.14361/9783839452578

ISSN of series: $2627-1907$

eISSN of series: $2703-0512$

Printed on permanent acid-free text paper. 